\title{
Towards a Brave New World of Corporate Governance Practices in Emerging Markets: The Case of Listed Banks in Romania
}

\author{
Delia DELIU \\ Post-Doctoral Researcher, Faculty of Economics and Business Administration - West University of \\ Timişoara, Timişoara, Romania \\ delia.deliu@e-uvt.ro
}

Received date: 19 May 2020; Accepted date: 29 July 2020; Published date: 5 October 2020

Copyright (C) 2020. Delia DELIU. Distributed under Creative Commons Attribution 4.0 International CC-BY 4.0

\begin{abstract}
Financial crises, in general, are putting a greater emphasis on the best practices regarding corporate governance in emerging economies. Boards of Directors are under great pressure to be transparent and accountable. In the same background, given the current socioeconomic context, due to the crisis generated by the new Coronavirus (CoVid-19) pandemic, the banking sector is under analogous levels of scrutiny, subject to a similar regulatory backlash. In this context, banks must not fail to fulfil the expectations of policy makers in particular, and society in general. The Code of Corporate Governance (CCG) issued by the Bucharest Stock Exchange (BSE) aims at creating an internationally attractive capital market in Romania, based on best practices, transparency and trust - pillars that encourage companies to build a strong relationship with their shareholders and other stakeholders, by an effective and transparent communication, as well as openness towards all potential investors. This paper aims to highpoint the degree of compliance of the banks listed on the BSE with the principles and provisions stipulated by the CCG in force. As such, the assessment consisted in measuring the corporate governance quality and effectiveness in the main Romanian banks: Banca Transilvania, BRD, Erste Group and Patria Bank. Evaluating corporate governance eminence is constructed by using the score function method in regards to disclosure and transparency practices, as proposed by BSE. In this respect, an investigation was performed, focusing on the mode in which the principles enforced by the BSE are respected. This goal is important due to the current sensitive socioeconomic environment, which, undoubtedly, makes the corporate governance in the banking sector a controversial subject. In this framework, valuable conclusions were reached, regarding a satisfactory compliance level with the CCG issued by BSE. The research emphasized a high level of adoption of the best practice doctrines.
\end{abstract}

Keywords: corporate governance; Bucharest Stock Exchange; Code of Corporate Governance; disclosure; transparency; compliance; banks.

JEL Classification: G21, G34, M21

Cite this Article as: Delia DELIU (2020), "Towards a Brave New World of Corporate Governance Practices in Emerging Markets: The Case of Listed Banks in Romania", Journal of Economics Studies and Research, Vol. 2020 (2020), Article ID 325840, DOI: 10.5171/2020.325840 


\section{Introduction}

Given the background of globalization and "the new economy", corporate governance's particularities within the banking sector increase the awareness of both practitioners and world organizations, concerned in advocating worldwide soundproof doctrines - whichever we talk about the Organisation for Economic Cooperation and Development (O.E.C.D.), Basel Committee's or the community law.

The first delineation of the concept dates back to the 1970s, when the Securities and Exchange Commission (SEC) brought the issue of corporate governance to the forefront when it was brought as a stance on the official corporate governance reform. The term appeared for the first time in 1976, in the Federal Register, the official journal of the Federal Government.

Corporate governance is defined by the O.E.C.D. as the set of relationships between a company's management and its stakeholders. In other words, it is the "procedures and processes according to which an organisation is directed and controlled". The corporate governance structure specifies the distribution of rights and responsibilities among the different participants in the organisation - such as the Board, managers, shareholders and other stakeholders - and lays down the rules and procedures for decision-making.

Correspondingly, the M.E.N.A.-O.E.C.D. Initiative (2019) drafts some guidelines regarding the effectiveness of corporate governance structures in banks, "given the prevailing role of banking institutions as a source of finance for the corporate sector. Improved board structures, administrative procedures and disclosure requirements could result in better governed banks, which are more likely to allocate capital efficiently".

Therefore, corporate governance incorporates managerial accountability, Board structure and shareholders rights.
High standards in the governance of banks and companies are essential for emerging markets and economic growth. Banks have a critical position in the progress of economies due to their major role in running the financial system.

Moreover, the banking industry is distinctive since it is concurrently consolidating and diversifying. Therefore, robust bank corporate governance is, indeed, an essential constituent for promoting a more resilient financial system (Deliu, 2019a).

Previous research highlights the consequences of banks' specific traits on their corporate governance framework, emphasising two foremost aspects: higher opaqueness and imperviousness and, of course, higher regulation.

Furthermore, unfortunately, over the last years, consequent to the 2007-2008 financial crisis, it is observed that Boards have not thrived in actually comprehending some specific risks in banks, so several discontinuity gaps have been encountered, as well as a sturdy lack of authority in terms of decisional issues, consisting in the spawn of a substantial trust deficit in credit institutions in general. This situation may repeat, as we speak, due to the turbulences, instability and volatility in the socio-economic environment, all spawned by the crisis generated by the current Coronavirus (CoVid-19) pandemic.

No one can accurately predict what will happen in the future, but we need to keep in mind some of the "changes that are probably waiting for us:

$\checkmark$ Corporate governance needs to be integrated into the business strategy of companies and not just as a mere compliance obligation;

$\checkmark \quad$ Effective corporate governance depends on management success;

$\checkmark$ The fundamental objective of the management body must be built on the sustained growth of the company;

$\checkmark$ Shareholders must have a long-term responsibility and economic interest in 
making decisions dutifully and responsibly;

$\checkmark \quad$ Well-governed companies must ensure good transparency towards all stakeholders" (Deliu, 2019b).

The way in which corporate governance systems will evolve in the future is hard to anticipate, however, the socio-economical revolutions in the business environment will make banks resort to changing processes, approaches, attitudes, as well as the stakeholder interaction models. The main scope of a corporate governance system is to ensure the sustainable growth in the current context of globalization. In this context, as Fülöp and Pintea (2015) observe, BSE should focus on one main priority: developing a Corporate Governance Index in order to efficiently assess the degree of applying and aligning with the Code's principles and provisions, as well as to measure the corporate governance performance. Vintilă and Moscu (2014) also deliberate that a respected legal framework of a corporate governance regulation is necessary in Romania, considering that corporate governance principles should be implemented through the development of a legally binding framework.

This study does not aim to investigate exhaustive topics associated with corporate governance in banks during crisis, since they have already been portrayed by previous tremendous researches - Mehran et al (2011), Mehran and Mollineaux (2012), de Haan and Vlahu (2013) - but it rather aims to outline an exploration of the capability of the Romanian bank system to stand by the corporate governance principles in the context of an imminent socio-economic crisis, that may be generated by the current CoVid-19 pandemic.

A critical feature of the Corporate Governance Codes is that they are implemented on the basis of the "complyor-explain" norm which provides disclosures of clear, accurate, relevant and up-to-date information regarding the compliance of the listed economic entities with the corporate governance principles.
In other words, a qualitative corporate governance finds its correspondence in efficient rules, policies and procedures of business management, administration and control.

The primary sources of the corporate governance legislation in Romania are the Companies Law, the Accounting Regulation, the Capital Markets Law, the Government Emergency Ordinance on Credit Institutions and Capital Adequacy, and the Government Emergency Ordinance $109 / 2011$ on state owned enterprises (amended by Law 111/2016).

In 2008, the Bucharest Stock Exchange (BSE) adopted a corporate governance code addressed to the listed companies, to be implemented as "comply-or-explain", the Code of Corporate Governance being revised in 2015, whereas a new Code entered into force in January 2016. Along with the Code, BSE also published a Compendium of Corporate Governance Practices and a Manual for Reporting Corporate Governance, in order to assist companies to implement the Code. The BSE has committed to have a leading role in monitoring the Code's implementation, as the European Bank for Reconstruction and Development (hereafter, EBRD) observes (ERBD, 2016).

A corporate governance code comprises a set of principles and recommendations for economic entities whose shares are admitted to trading in the regulated market, hence, by emphasizing best practices and based on transparency and trust, it aims at building an internationally attractive capital country in the region. Henceforth, it encourages companies to build a strong relationship both with their shareholders and stakeholders, through an effective and transparent communication and by showing openness towards all potential investors.

BSE has taken a significant step towards better, more qualitative corporate governance at Romania's listed economic entities, by adopting a new corporate governance code in 2015, developed 
together with EBRD. This new Code replaced the original Code which was issued in 2001 and revised in 2008.

The new corporate governance framework promotes higher standards of governance and transparency through a new system of compliance and enforcement (BSE, 2015), aiming to "improve confidence in the listed companies through promoting positive developments in the corporate governance of these companies", by:

- Putting emphasis on the value of establishing a continuous relationship with investors,

- Highlighting the quality of disclosure,

- Deploying new measures so as to lay down a solid base for the capital market in Romania.

This paper aims to measure the degree to which the banks listed on the Bucharest Stock Exchange (BSE) comply with the principles and provisions of the Code of Corporate Governance issued by the BSE regarding the:

A. Responsibilities of the Board (either the Board of Directors - in a one-tier system, or the Supervisory/Management Board in a two-tier system) vs. the responsibilities of the executive management,

B. Reliability and efficiency of the risk management system and internal control system,

C. Fair rewards and motivation of the members of the Board;

D. Added value created through the relationship with the current and potential investors.

By means of the Corporate Governance Statement, included in the Annual Report in a separate section, the listed banks perform a self-assessment of how to respect the provisions with which they should comply and, subsequently, outline the measures taken to abide by, taking into consideration the aspects that are not yet fully met.
Bunea (2013) and Manea (2015) both conclude some key features that are "pertinent for analysing and testing the degree of enabling corporate governance principles in banks", these comprising: tasks and duties of both governance structures and control structures (with an emphasis on the Supervisory Board's responsibilities); monitoring structures' roles (and possible contiguous conflicts of interest); minority shareholders' and interest owners' status; corporate governance risks and the amendments made to the internal control function (in order to prevent and detect these risks); role of the internal audit; and importance of ethics.

Banking governance - and particularly the banks' non-executive directors - must recognize the clear and present danger to the sector, and use this crisis as an opportunity to transform banks into respected corporate citizens rather than the perennial corporate villain.

\section{Research Methodology}

This study seeks to explore the degree to which the key concepts, principles and techniques typical to corporate governance are spread and enabled, by taking the four banks that are currently listed on BSE as a reference. The research methodology used; the observation, which was based mainly on the analysis of the Annual Reports and on the "Comply-or-Explain" Statement published by the banks analysed in 2018. The analysed sample consists of four banks that are currently listed on BSE: Banca Transilvania (TLV), BRD (BRD), Erste Group (EBS) and Patria Bank (PBK), included in the Monthly Bulletin drawn up by the BSE in December 2018.

Since this paper's purpose is to assess the degree of applying sound corporate governance principles by the significant players in the Romanian banking system, the research methodology was fundamentally based on non-participating observation, which is an analysis of the disclosed documents published on the websites of the analysed banks. Moreover, a scoring method was used (Spătăcean and Ghiorghiţă, 2012; Manea, 2015; Deliu, 
2020), so as to assess the degree of smearing corporate governance principles and transparency disclosing elements, which permitted transforming assertive and qualitative data into numerical quantitative data.

Data collection finds its correspondence in developing methods of mediated information collection from examining the Code of Corporate Governance issued by the BSE, Corporate Governance Codes made public on the official websites of the analysed banks, as well as their published Annual Reports on 31 ${ }^{\text {st }}$ of December 2018, namely the "Comply-or-Explain" Statement. Therefore, the research required both a qualitative and a quantitative approach, on the basis of the empirical data collected out of the sample of the four banks that are currently listed on BSE.

The qualitative approach is enlightened by the fact that the research has prerequisite interpretations, clarifications, explanations and deep understanding of the analysed phenomena, while the quantitative method has concentrated on quantifying through numerical expressions by using the score system for each bank from the sample.

\section{Data}

According to BSE (2015), the purpose of the Code of Corporate Governance Code is to create an internationally attractive capital market in Romania, based on best practices, transparency and trust, namely to determine whether the listed entities comply, to a great extent, with all the principles and provisions or not.

As stated by the BSE's Code of Corporate Governance, the general principles and the provisions to comply with , applied and accounted for by the listed companies, are structured in four sections, as follows:
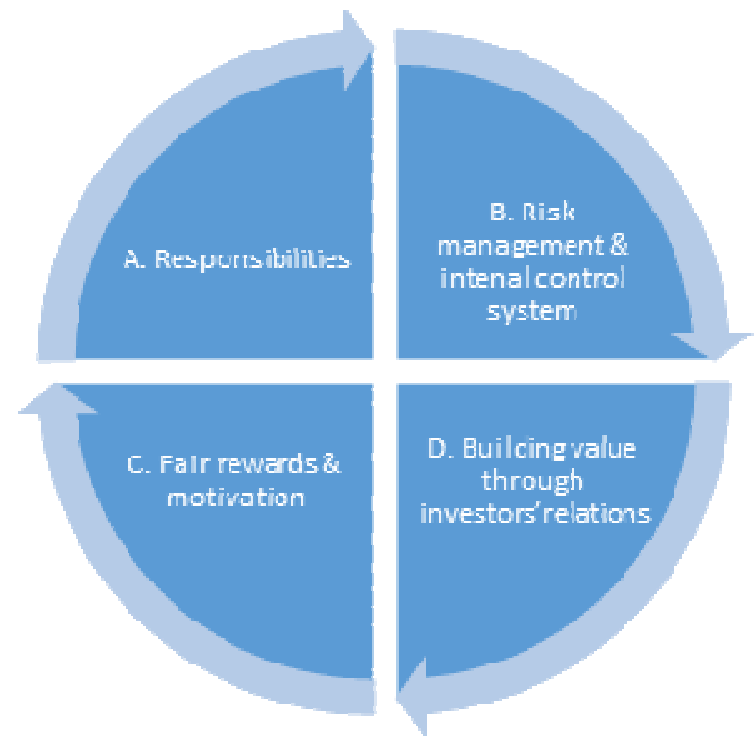

Fig. 1: Bucharest Stock Exchange Market's Code of Corporate Governance

Source: own projection, after B.S.E.'s Code of Corporate Governance (2015)

(https://www.bvb.ro/info/Rapoarte/Diverse/EN G Corporate\%20Governance\%20Code WEB revi sed.pdf)
On one hand, the principles postulated in BSE's Code of Corporate Governance are the following: 
Table 1: Corporate governance - general principles, as per BSE's Code of Corporate Governance (2015)

\begin{tabular}{|c|c|}
\hline Section & General principles \\
\hline $\begin{array}{l}\text { Section A - } \\
\text { Responsibilities }\end{array}$ & $\begin{array}{l}\text { i. The role of the Board of Directors in a one-tier board system and the role of the Supervisory } \\
\text { Board/Management Board in a two-tier board system should be clearly defined and documented in the } \\
\text { company's articles of association, internal regulations and/ or other similar documents. The Board should } \\
\text { ensure that the company's articles of association, the resolutions of the general meeting of shareholders, and } \\
\text { the internal regulations of the company include a clear distinction of powers and competencies between the } \\
\text { general meeting of shareholders, the Board and the executive management. } \\
\text { ii. The Board should be structured in such a way that allows it to diligently fulfill its duties. The Board should } \\
\text { meet sufficiently on a regular basis to discharge its duties effectively. } \\
\text { iii. The Board should ensure that a formal, rigorous and transparent procedure is put into place regarding the } \\
\text { appointment of new members to the Board. } \\
\text { iv. There should be a clear division of responsibilities between the Board and the executive management. } \\
\text { v. The Board and its committees should have the appropriate balance of skills, experience, gender diversity, } \\
\text { knowledge and independence to enable them to effectively perform their respective duties and } \\
\text { responsibilities. It is recommended for the majority of the non-executive members of the Board of Directors or } \\
\text { the Supervisory Board to be independent. All members of the Board should be able to allocate sufficient time } \\
\text { to the company to discharge their responsibilities effectively. The Board should be appropriately informed to } \\
\text { enable it to discharge its duties. } \\
\text { vi. Board members must strictly observe the secrecy of the proceedings, debates and decisions taken, unless } \\
\text { otherwise decided by the Board or unless regulations in force require the appropriate disclosure. }\end{array}$ \\
\hline $\begin{array}{l}\text { Section B- } \\
\text { Risk } \\
\text { management \& } \\
\text { internal } \\
\text { control system }\end{array}$ & $\begin{array}{l}\text { i. The company should have in place an efficient risk management and internal control system. The Board } \\
\text { should determine the principles of and the approaches to the risk management and internal control system in } \\
\text { the company. } \\
\text { ii. The company should arrange for the internal audits to independently evaluate, on a regular basis, the } \\
\text { reliability and efficiency of the risk management and internal control system and the corporate governance } \\
\text { practices. The Board of Directors or Supervisory Board, as the case may be, should set up an independent audit } \\
\text { committee capable of ensuring the integrity of financial reporting and of the internal control system, including } \\
\text { the internal and external audit processes. } \\
\text { iii. The company will ensure that all related party transactions are considered on their merits in a manner that } \\
\text { ensures the independence and protection of the interests of the company, compliant with the restrictions set } \\
\text { out in the related legislations and fairly disclosed to the shareholders and potential investors. The definition of } \\
\text { related parties follows that of the International Accounting Standard } 24 \text {. }\end{array}$ \\
\hline $\begin{array}{l}\text { Section } C- \\
\text { Fair rewards \& } \\
\text { motivation }\end{array}$ & $\begin{array}{l}\text { i. The level of remuneration should be sufficient to attract, retain and motivate skilful and experienced people as } \\
\text { members of the Board and the management. The Board should ensure transparency related to remuneration } \\
\text { matters. The shareholders should be provided with relevant information in order to understand the principles } \\
\text { applied by the company regarding the remuneration policy, which is based on fair rewards and motivation for } \\
\text { Board members, and for the CEO or Management Board. } \\
\text { ii. A company should have a remuneration policy, and rules defining that policy. It should determine the form, } \\
\text { structure and level of remuneration of members of the Board, the CEO and, when applicable, members of the } \\
\text { Management Board. }\end{array}$ \\
\hline $\begin{array}{l}\text { Section D- } \\
\text { Building value } \\
\text { through } \\
\text { investors' } \\
\text { relations }\end{array}$ & $\begin{array}{l}\text { i. The company should disseminate the most important information both in Romanian and English, to enable } \\
\text { Romanian and foreign investors to have access to the same information at the same time. } \\
\text { ii. A company should do its best to enable its shareholders to participate in general meetings, aiming at using } \\
\text { electronic communication means through (a) live broadcast of general meetings and/or (b) live bilateral } \\
\text { communication where shareholders may express themselves during a general meeting from a location other } \\
\text { than that of the general meeting, as long as this is in line with legislations regarding data processing. } \\
\text { iii. A company should aim to provide for an electronic voting system at general meetings, including remote } \\
\text { electronic voting. }\end{array}$ \\
\hline
\end{tabular}

Source: B.S.E.'s Code of Corporate Governance (2015)

(https://www.bvb.ro/info/Rapoarte/Diverse/EN

G_Corporate\%20Governance\%20Code_WEB_revi sed.pdf)

It is observed that through enunciating these 14 general principles, BSE maintains a mechanism based on the "comply-orexplain" principle which gives the market clear, accurate and actual information about the listed companies' compliance with corporate governance rules.

On the other hand, the provisions stipulated in BSE's Code of Corporate of Governance are, as follows: 
Table 2: Corporate governance - provisions to comply with, as per BSE's Code of Corporate Governance (2015)

\begin{tabular}{|c|c|}
\hline Section & Provisions \\
\hline - & 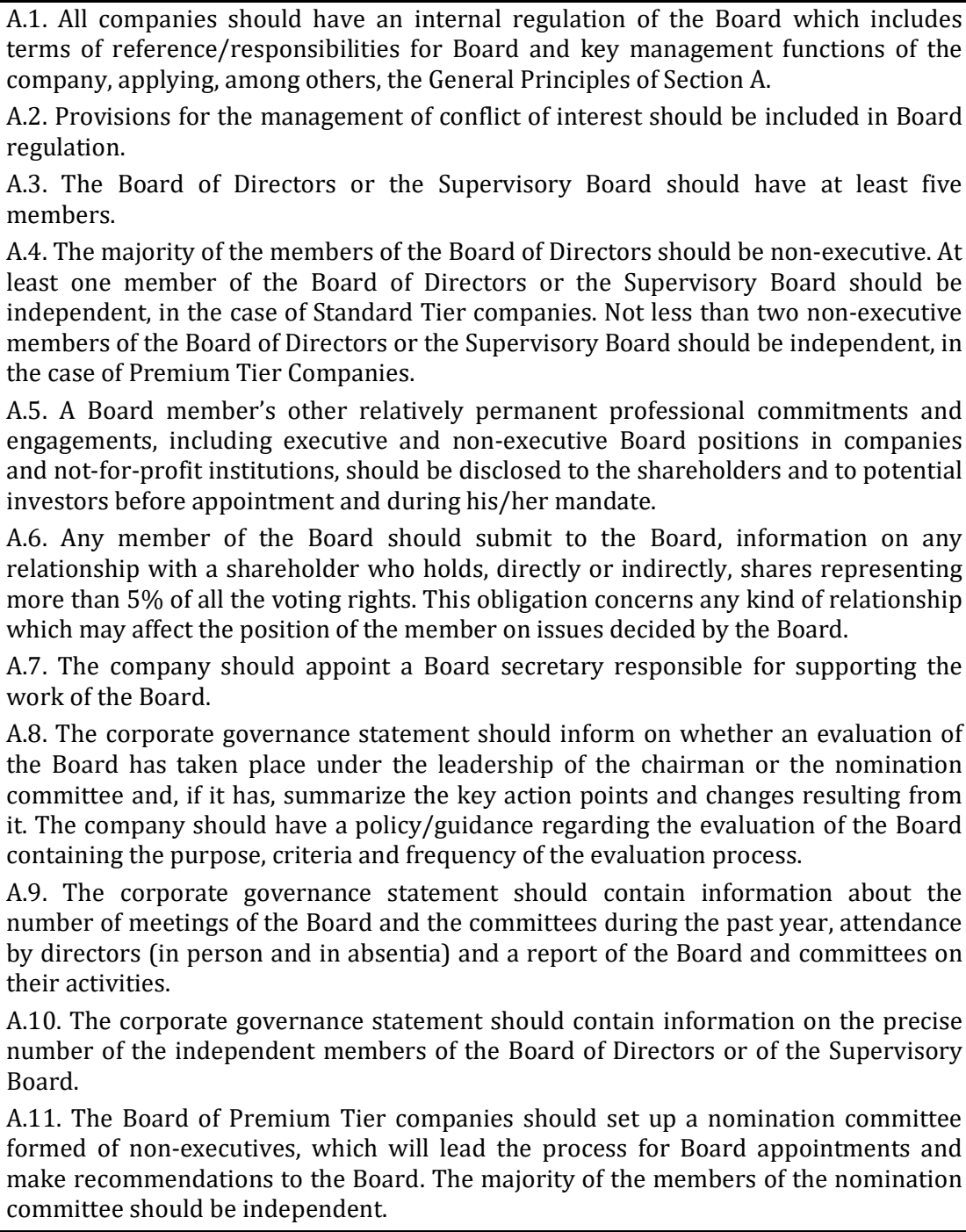 \\
\hline $\begin{array}{l}\text { Section B- } \\
\text { Risk } \\
\text { management \& } \\
\text { internal } \\
\text { control system }\end{array}$ & $\begin{array}{l}\text { B.1. The Board should set up an audit committee, and at least one member should be } \\
\text { an independent non-executive. The majority of the members, including the chairman, } \\
\text { should have proven adequate qualifications relevant to the functions and } \\
\text { responsibilities of the committee. At least one member of the audit committee should } \\
\text { have proven an adequate auditing or accounting experience. In the case of Premium } \\
\text { Tier companies, the audit committee should be composed of at least three members, } \\
\text { and the majority of the audit committee should be independent. } \\
\text { B.2. The audit committee should be chaired by an independent non-executive member. } \\
\text { B.3. Among its responsibilities, the audit committee should undertake an annual } \\
\text { assessment of the internal control system. } \\
\text { B.4. The assessment should consider the effectiveness and scope of the internal audit } \\
\text { function, the adequacy of risk management and internal control reports to the audit } \\
\text { committee of the Board, management's responsiveness and effectiveness in dealing } \\
\text { with identified internal control failings or weaknesses and their submission of relevant } \\
\text { reports to the Board. }\end{array}$ \\
\hline
\end{tabular}




\begin{tabular}{|c|c|}
\hline & $\begin{array}{l}\text { B.5. The audit committee should review conflicts of interests in the transactions of the } \\
\text { company and its subsidiaries with related parties. } \\
\text { B.6. The audit committee should evaluate the efficiency of the internal control system } \\
\text { and risk management system. } \\
\text { B.7. The audit committee should monitor the application of statutory and generally } \\
\text { accepted standards of internal auditing. The audit committee should receive and } \\
\text { evaluate the reports of the internal audit team. } \\
\text { B.8. Whenever the Code mentions reviews or analysis to be exercised by the Audit } \\
\text { Committee, these should be followed by cyclical (at least annual), or ad-hoc reports to } \\
\text { be submitted to the Board afterwards. } \\
\text { B.9. No shareholder may be given an undue preference over other shareholders with } \\
\text { regard to transactions and agreements made by the company with shareholders and } \\
\text { their related parties. } \\
\text { B.10. The Board should adopt a policy ensuring that any transaction of the company } \\
\text { with any of the companies with which it has close relations, that is equal to or more } \\
\text { than } 5 \% \text { of the net assets of the company (as stated in the latest financial report), } \\
\text { should be approved by the Board following an obligatory opinion of the Board's audit } \\
\text { committee, and fairly disclosed to the shareholders and potential investors, to the } \\
\text { extent that such transactions fall under the category of events subject to disclosure } \\
\text { requirements. } \\
\text { B.11. The internal audits should be carried out by a separate structural division } \\
\text { (internal audit department) within the company or by retaining an independent third- } \\
\text { party entity. } \\
\text { B.12. To ensure the fulfilment of the core functions of the internal audit department, it } \\
\text { should report functionally to the Board via the audit committee. For administrative } \\
\text { purposes and in the scope related to the obligations of the management to monitor } \\
\text { and mitigate risks, it should report directly to the chief executive officer. }\end{array}$ \\
\hline $\begin{array}{l}\text { Section } C- \\
\text { Fair rewards \& } \\
\text { motivation }\end{array}$ & $\begin{array}{l}\text { C.1 The company should publish a remuneration policy on its website and include, in } \\
\text { its annual report, a remuneration statement on the implementation of this policy } \\
\text { during the annual period under review. }\end{array}$ \\
\hline $\begin{array}{l}\text { Section D- } \\
\text { Building value } \\
\text { through } \\
\text { investors' } \\
\text { relations }\end{array}$ & $\begin{array}{l}\text { D.1. The company should have an Investor Relations function - indicated by person(s) } \\
\text { responsible or an organizational unit to the general public. In addition to the } \\
\text { information required by legal provisions, the company should include on its corporate } \\
\text { website a dedicated Investor Relations section, both in Romanian and English, with all } \\
\text { the relevant information of interest for investors. } \\
\text { D.2. A company should have an annual cash distribution or dividend policy, proposed } \\
\text { by the CEO or the Management Board and adopted by the Board, as a set of directions } \\
\text { the company intends to follow regarding the distribution of the net profit. The annual } \\
\text { cash distribution or dividend policy principles should be published on the corporate } \\
\text { website. } \\
\text { D.3. A company should have adopted a policy with respect to forecasts, whether they } \\
\text { are distributed or not. Forecasts mean the quantified conclusions of studies aimed at } \\
\text { determining the total impact of a list of factors related to a future period (so called } \\
\text { assumptions). Naturally, such a task is based upon a high level of uncertainty, with } \\
\text { results sometimes significantly differing from the forecasts initially presented. The } \\
\text { policy should provide for the frequency, period envisaged, and content of forecasts. } \\
\text { Forecasts, if published, may only be part of annual, semi-annual or quarterly reports. } \\
\text { The forecast policy should be published on the corporate website. } \\
\text { D.4. The rules of the general meetings of shareholders should not restrict the } \\
\text { participation of shareholders in general meetings and the exercising of their rights. } \\
\text { Amendments of the rules should take effect, at the earliest, as of the next general } \\
\text { meeting of shareholders. } \\
\text { D.5. The external auditors should attend the shareholders' meetings when their } \\
\text { reports are presented there. } \\
\text { D.6. The Board should present to the annual general meeting of shareholders a brief } \\
\text { assessment of the internal controls and significant risk management system, as well as } \\
\text { opinions on issues subject to resolution at the general meeting. }\end{array}$ \\
\hline
\end{tabular}




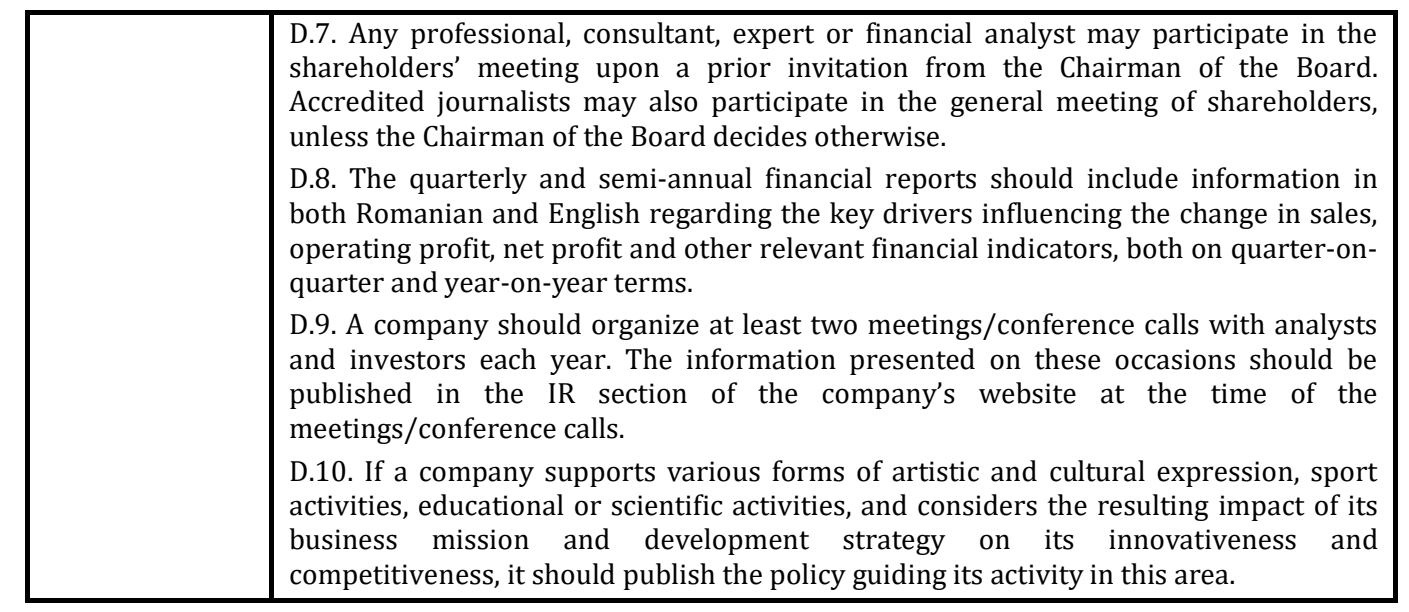

Source: B.S.E.'s Code of Corporate Governance (2015)

(https://www.bvb.ro/info/Rapoarte/Diverse/EN G Corporate\%20Governance\%20Code WEB revi sed.pdf)

It is also observed that the new Code is much precise and more focused on what is required form the listed companies, providing a clear list of functions that are expected from the corporate governance structures, therefore, complementing the law in force.

\section{Method}

The aim of the paper is to assess the degree of compliance of the Romanian banks that are listed on BSE with the Code of
Governance issued by BSE. Hence, by using a scoring system, the enounciative (and qualitative) data were transformed into numerical (and quantitative data), revealing, henceforth, the extent to which they align with the principles and comply with the provisions presented above.

Taking into consideration the fact that in the "Comply-or-Explain" Statement, the banks, by performing a self-assessment, have four options that reflect either full compliance, satisfactory compliance, unsatisfactory compliance or noncompliance, the following table presents the used scoring system, consistent with the response disclosed by the banks:

Table 3: Significance of the conformity score given to the collected and interpreted information

\begin{tabular}{|c|l|l|}
\hline $\begin{array}{c}\text { Conformity } \\
\text { score }\end{array}$ & \multicolumn{1}{c|}{$\begin{array}{c}\text { Compliance } \\
\text { degree }\end{array}$} & \multicolumn{1}{c|}{ Significance } \\
\hline $\mathbf{0}$ & Non-compliance & $\begin{array}{l}\text { The analysed bank has not disclosed any relevant document or report } \\
\text { concerning corporate governance (The Statement Enforce or Explain, } \\
\text { Annual Reports, etc.). }\end{array}$ \\
\hline $\mathbf{1}$ & Satisfactory & $\begin{array}{l}\text { The analysed bank has disclosed satisfactory information (partial data, } \\
\text { outdated information) which does not permit settling the cases regarding } \\
\text { the soundness of corporate governance and/or making any } \\
\text { recommendations. }\end{array}$ \\
\hline $\mathbf{2}$ & $\begin{array}{l}\text { Unsatisfactory } \\
\text { compliance }\end{array}$ & $\begin{array}{l}\text { The documents regarding corporate governance are publicly disclosed on } \\
\text { the official websites in a proportion of } \mathbf{7 0 \% , ~ t h e ~ i n f o r m a t i o n ~ a v a i l a b l e ~} \\
\text { allow for settling the issues related to corporate governance at a medium } \\
\text { level. }\end{array}$ \\
\hline $\mathbf{3}$ & Full compliance & \begin{tabular}{l} 
Information dissemination meets the maximum of 100\%, by offering \\
\hline
\end{tabular} \\
\hline
\end{tabular}


\begin{tabular}{|l|l|l|}
\hline & $\begin{array}{l}\text { complete, accurate, transparent and exhaustive disclosed reports, in total } \\
\text { accordance with the principles of an effective corporate governance. }\end{array}$ \\
\hline
\end{tabular}

Source: own projection, after Deliu (2020)

Considering this scoring system, as well as all the 4 sections of the Code of Corporate Governance issued by BSE, comprising 11 provisions to comply with (in section A), 12 provisions (in section $B$ ), 1 provision (in section C) and 10 provisions (in section D) a bank can obtain:

- for section A - a maximum of 33 points,

- for section B - a maximum of 36 points,

- for section $\mathrm{C}$ - a maximum of 3 points,

- for section D - a maximum of 30 points.
Hence, in total, a bank can sum up 102 points, which reflects absolute full compliance with all the sections of the BSE's Code of Corporate Governance. Henceforth, for the studied banks, the maximum score that can be reached is 408 points.

\section{Results and Discussions}

By analysing the "Comply-or-Explain" Statement disclosed for each of the 4 banks and in accordance with the proposed scoring system, the level of conformity with the principles and provisions depicted in the Code of Governance issued by the BSE was calculated:

Table 4: Quantitative determinations regarding the level of conformity with the BSE's Code of Corporate Governance

\begin{tabular}{|c|c|c|c|}
\hline \multirow{2}{*}{$\begin{array}{r}\text { Category } \\
\text { Level of } \\
\text { conformity }\end{array}$} & \multirow{2}{*}{$\begin{array}{r}\text { Maximum score } \\
{[\mathrm{pts}]}\end{array}$} & \multicolumn{2}{|c|}{ Compliance } \\
\hline & & $\begin{array}{l}\text { Obtained score } \\
\text { [as at Dec, 31, 2018] }\end{array}$ & $\begin{array}{l}\text { Degree of compliance } \\
{[\%]}\end{array}$ \\
\hline TOTAL CGC.c score & 408 & 357 & $87.50 \%$ \\
\hline Section A score & 132 & 130 & $98.48 \%$ \\
\hline Section B score & 144 & 118 & $81.94 \%$ \\
\hline Section C score & 12 & 10 & $83.33 \%$ \\
\hline Section D score & 120 & 99 & $82.50 \%$ \\
\hline
\end{tabular}

Source: own projection

From the analysis carried out, it was revealed that the banks analysed in the sample comply, to a great extent, with the provisions of the Code of Corporate Governance.

However, the lowest result was obtained, unsurprisingly, in section $B$, which refers to risk management and internal control. Over the last years, subsequent to the 2007-2008 crisis, the bank practitioners did not seem to actually understand the risks and, therefore, banks do not periodically review and make amendments to the internal control function in accordance to the bank's risk profile.

Section D also acquired a low result, due to the fact that banks should adopt a policy with respect to forecasts, whether they are distributed or not. Moreover, banks, even if they may have an Investor Relations function, they do not make the adequate disclosures and do not have a dedicated Investor Relations section on their website, 
both in Romanian and English, as advised by BSE.
Graphically, the scores obtained by the studied banks regarding the level of compliance with the provisions of sections $\mathrm{A}, \mathrm{B}, \mathrm{C}$ and $\mathrm{D}$ are reflected as follows:

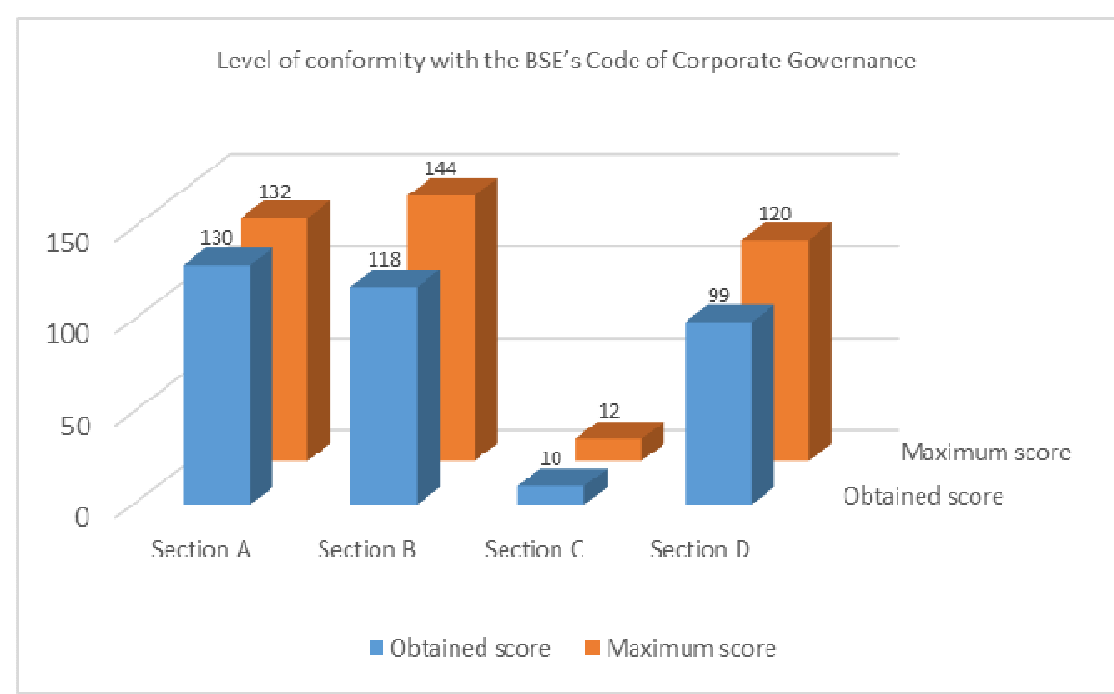

Fig. 2: Level of conformity with the BSE's Code of Corporate Governance Source: own projection

The analysis of the level of compliance with the principles and provisions depicted in the Code of Governance issued by the BSE in each section is presented in the descriptive statistics below:

\section{Table 5: Descriptive statistics}

\begin{tabular}{|c|c|c|c|c|c|}
\hline & Section A & Section B & Section C & Section D & Total CGC.c \\
\hline Mean & 32.5 & 29.5 & 2.5 & 24.75 & 92 \\
\hline Standard Error & 0.2886 & 0.5 & 0.2887 & 0.25 & 0.4082 \\
\hline Median & 32.5 & 29 & 2.5 & 25 & 92 \\
\hline Mode & 32 & 29 & 3 & 25 & 92 \\
\hline $\begin{array}{l}\text { Standard } \\
\text { Deviation }\end{array}$ & 0.5773 & 1 & 0.5774 & 0.5 & 0.8164 \\
\hline $\begin{array}{l}\text { Sample } \\
\text { Variance }\end{array}$ & 0.3333 & 1 & 0.3333 & 0.25 & 0.6666 \\
\hline Kurtosis & -6 & 4 & -6 & 4 & 1.5 \\
\hline Skewness & 0 & 2 & 0 & -2 & 0 \\
\hline Range & 1 & 2 & 1 & 1 & 2 \\
\hline Minimum & 32 & 29 & 2 & 24 & 91 \\
\hline Maximum & 33 & 31 & 3 & 25 & 93 \\
\hline Sum & 130 & 118 & 10 & 99 & 368 \\
\hline Count & 4 & 4 & 4 & 4 & 4 \\
\hline
\end{tabular}

Source: own projection 
Section A's provisions seem to be the ones with which most banks comply (98.48\% compliance), especially in terms of:

$\oplus$ the internal regulation of the Board in terms of reference and responsibilities for the Board and key management functions of the banks;

$\oplus$ managing conflicts of interest;

$\oplus$ the composition of the Boards;

$\oplus$ the policies regarding the evaluation of the Boards;

$\oplus$ the disclosed information regarding the number of meetings of the Board and of the committees;

$\oplus$ appointing a nomination committee (all banks being part of the Premium Tier entities).

However, some deficiencies are observed, most of them being related to:

$\otimes$ insufficient information on the precise number of the independent members of the Boards.

The highest and the maximum score of section (33) is obtained by 2 banks that fully comply with the provisions of the Code in terms of the responsibilities of the Boards. Within this section, the model's amplitude is 27 and it reflects the difference between the maximum and the minimum score obtained by the companies under study.

Conversely, Section B's provisions seem to be the ones with which banks do not comply (only $81.94 \%$ compliance), especially when it comes to:

$\otimes \quad$ the audit committee's assessment regarding the effectiveness and scope of the internal audit function;

$\otimes \quad$ the adequacy of risk management and internal control reporting to the audit committee of the Board; $\otimes \quad$ management's responsiveness and effectiveness in dealing with identified internal control failings or weaknesses and their submission of relevant reports to the Board;

$\otimes$ the lack of cyclical or ad-hoc reports.

The strong points refer to:

$\oplus$ monitoring of the application of statutory and generally accepted standards of internal auditing;

$\oplus$ the existence of a separate structural division (internal audit department) within the bank/ an independent third-party entity.

It is relevant to notice that within this section, the model's amplitude is the highest (2), reflecting the higher differences, namely the variance between the maximum and the minimum score obtained by the banks under scrutiny.

In regards to Section $C$, there is only one provision that must be respected by the listed banks which refers to the fair reward and motivation regarding the remuneration policy of the members Boards. The lowest score obtained is 2, while the highest score is 3 , this reveals that:

some banks fully comply with the provisions regarding the publication of the guidelines and arguments underlying the remuneration policy of the members of the Boards, while some banks still do not provide a full disclosure of the aforementioned aspects. Thus, the obtained results indicate the above average compliance of the banks with the provisions of the Code (83.33\%).

Section $D$ is another problematic section, with a total compliance degree of $82.50 \%$. The lowest score obtained is 24 points (out of maximum 30 points), which reveals that out of the 4 banks, some do not comply with the provisions of the Code of 
Governance regarding building the value through relationships with investors, especially when it comes to:

$\otimes$ having an Investor Relations function;

$\otimes$ adoping a policy with respect to forecasts;

$\otimes$ including specific information in the quarterly and semi-annual financial reports regarding the key drivers influencing the operational revenues.

The strong points relate mainly to the external auditors, namely to:

$\oplus \quad$ the presence of external auditors in the shareholders' meetings.

In conclusion, from a global perspective, the level of compliance with the principles and provisions of the Code of the 4 studied banks is reasonably high (87.50\%).

Weaknesses of those charged with governance may have to be addressed in the future, requiring efforts for revision, enhancement and improvement. These weaknesses may relate to:

$\otimes \quad$ a lack of diversity in the composition of the Supervisory Board and Executive Board and a lack of a clear and concrete policy on gender balance, social and cultural origin, professional profile and education;

$\otimes$ no real evaluation of the performances of the members of the two boards of management;

$\otimes$ an unsatisfactory supervision of risk management and risk exposure framework;

$\otimes$ a lack of authority from the risk management function, so that high risk activities can be stopped in time;

$\otimes$ a lack of diversification in risk management, often limited only to those categories of risk which are considered as priority and, implicitly, the inability to see $g$ the overall picture, i.e. the totality of risks to which the credit institution is exposed;

$\otimes \quad$ unreasonable and disproportionate directors' remuneration, based on a shortterm value of the bank's action, as being the only performing criteria (Deliu, 2020).

\section{Conclusions}

Corporate governance creates a "brave new world", in which entities have to either comply or explain.

The "Comply-or-Explain" Statement reflects the extent to which the corporate governance guidelines are applied and enforced by the listed entities, through a self-assessment that reflects the either full compliance, satisfactory compliance, unsatisfactory compliance or noncompliance with the provisions of the Code.

The purpose of corporate governance is to facilitate an effective, entrepreneurial and prudent management that can deliver longterm success for an entity activating in the banking sector.

It's the system by which banks are directed and controlled, providing a measure for shareholders regarding the appropriateness of the governance structures.

Therefore, a cornerstone of the Code Corporate Governance issued by the BSE is the principle of "comply-or-explain". Banks in Romania have to report each year how they have applied the principles of the Code, so that investors can evaluate the actions taken.

In this framework, valuable conclusions were reached regarding a satisfactory compliance level with corporate governance requirements in regards to the Romanian banks that are listed on BSE. In this sense, the research emphasized, to some degree, a high level of adoption of the principles and provisions. 
It is emphasized that it would be timely and beneficial that BSE would develop a Corporate Governance Index in order to efficiently assess the degree of applying and aligning with the Code's principles and provisions, as well as to measure the corporate governance performance of the entities listed on the BSE Market.

\section{References}

- Bunea, M. (2013), 'The Corporate Governance Impact on Banking Performance Increase', Cross-Cultural Management Journal, 15(02), 11-21.

- De Haan, J. and Vlahu, R. (2013), 'Corporate Governance of Banks: A Survey', Working Paper De Nederlandsche Bank, no. 386.

- Deliu, D. (2019), 'Brief Critical Analysis of the Main Corporate Governance Traits within Romanian Banks Listed on Bucharest Stock Exchange', Proceedings of the $34^{\text {th }}$ International Business Information Management Association (I.B.I.M.A.) Conference, ISBN: $\quad$ 978-0-9998551-3-3, 13-14 November 2019, Madrid, Spain.

- Deliu, D. (2019), 'Corporate Governance Issues and Vulnerabilities in the Wake of a Global Financial Crisis', Proceedings of the 6th International Multidisciplinary Scientific Conference - SOCIAL SCIENCES, ARTS \& HUMANITIES, SWS International Scientific Conference on Social Sciences, vol. Political Sciences, Law, Economics \& Finance, ISBN: 978619-7408-91-1, 24 August-02 September 2019, Albena, Bulgaria, 6(1), 297-307.

- Deliu, D. (2020), 'Key Corporate Governance Features within Romanian Banks Listed on Bucharest Stock Exchange: A Thorough Scrutiny and Assessment', Journal of Eastern Europe Research in Business and Economics, 271202.

- Fülöp, M-T. and Pintea, M-O. (2015), 'The Link between Corporate Governance and Performance Evidence', Intercultural Management, 17(1), 81-90.

- Manea, M-D. (2015), 'Corporate Governance within the Romanian Bank
System', Procedia Economics and Finance, 27, 454-459.

- Mehran, H., Morrison, A. and Shapiro, J. (2011), 'Corporate Governance and Banks: What Have We Learned from the Financial Crisis?', Federal Reserve Bank, New York, Staff Report, no. 502.

- Mehran, H. and Mollineaux, L. (2012), 'Corporate Governance of Financial Institutions', Federal Reserve Bank, New York, Staff Report, no. 539.

- Spătăcean, I.O. and Ghiorghiţă, L. (2012), 'Testing Compliance with Corporate Governance Principles on the Romanian Capital Market', Studia Universitatis Petru Maior, Series Oeconomica, 1, 70-87.

- Vintilă, G. and Moscu, R. (2014), 'Compliance with the Romanian Corporate Governance Code. Evidences from the Companies Listed on Bucharest Stock Exchange', Journal of Public Administration, Finance and Law, 6, 235-244.

- $* * *$ - Bucharest Stock Exchange. (2015), Code of Corporate Governance. [Online]. Bucharest Stock Exchange. [01.03.2020]. Available:

- https://www.bvb.ro/info/Rapoarte/Di verse/ENG Corporate\%20Governance \%20Code WEB revised.pdf.

- *** - Bucharest Stock Exchange. Compendium of Corporate Governance Practices. [Online]. Bucharest Stock Exchange. [01.03.2020]. Available:

- https://www.bvb.ro/info/Rapoarte/Di verse/EN EBRD BVB Compendium 1 8.09.2015 note\%206.01.2017.pdf.

- *** - Bucharest Stock Exchange. Manual for Reporting Corporate Governance. [Online]. Bucharest Stock Exchange. [01.02.2020]. Available:

https://www.bvb.ro/info/Rapoarte/Di verse/EN_EBRD_Manual\%20for\%20r eporting_CG_18.09.2015_note\%206.01. 2017.pdf.

- *** - European Bank for Reconstruction and Development. (2016). Corporate Governance in Transition Economies. Romania Country Report. [Online]. European Bank for Reconstruction and Development. [01.03.2020]. Available: https://www.ebrd.com/documents/le gal-reform/dpdf-corporate- 
governance-romania.pdf.

- $\quad * * *$ - M.E.N.A.-O.E.C.D. Initiative. 2019.

Policy Brief on Corporate Governance of Banks. Building Blocks. [Online]. The Organisation for Economic Cooperation and Development (O.E.C.D.). [01.03.2020]. Available:

http://www.oecd.org/corporate/ca/co rporategovernanceprinciples/381873 17.pdf.

- $\quad * * *$ - The Organisation for Economic Co-operation and Development
(O.E.C.D). Principles of Corporate Governance. [Online]. The Organisation for Economic Co-operation and Development (O.E.C.D.). [01.03.2020]. Available: http://www.oecd.org/corporate/princ iples-corporate-governance/. 